\title{
Analysis and Research on Energy-Saving Reconstruction of Building Heating System
}

\author{
Yongqiang Liu (iD) and Zhanfang Huang \\ School of Construction Engineering, Shandong University of Technology, Zibo 255049, Shandong, China \\ Correspondence should be addressed to Yongqiang Liu; yongqiangliu110@163.com
}

Received 14 January 2021; Revised 9 February 2021; Accepted 14 March 2021; Published 14 April 2021

Academic Editor: Di Wang

Copyright ( 2021 Yongqiang Liu and Zhanfang Huang. This is an open access article distributed under the Creative Commons Attribution License, which permits unrestricted use, distribution, and reproduction in any medium, provided the original work is properly cited.

\begin{abstract}
A building heating system had high energy consumption and did not meet the requirements of environmental protection, so it was needed to be reformed. After recalculating the heat load, it was found that the heat source, pipe network specification, and radiator area of the original heating system were oversized. After comparing with a gas-fired boiler, the heat source was transformed into the water source heat pump system. The water supply temperature of the water source heat pump was lower than that of the boiler. Generally, it seemed necessary to increase the radiator area. However, after calculation and verification, when the supply and return water temperature was $65 / 58^{\circ} \mathrm{C}$, the system operated continuously and the original pipe network and radiator could still ensure the indoor temperature of $16^{\circ} \mathrm{C}$. The total cost of transformation was 11.5 million Chinese Yuan. After analyzing the operation data of the new system, the water source heat pump system could save $82.6 \%$ energy compared with the original system and $29.6 \%$ cost compared with the central heating system. The transformation is successful, and the experience is worth popularizing.
\end{abstract}

\section{Introduction}

In recent years, with more stringent environmental policies, coal-fired boilers for heating are restricted. Many places have been actively promoting "coal to electricity" or "coal to gas" $[1,2]$. For buildings outside the scope of central heating, the selection of heat source type needs to consider the factors of technology, environmental protection, energy conservation, and economy. This requires engineers to determine the form of heat source according to local conditions, not mechanically.

Many professionals have studied the heating transformation. Zhang [3] summarized the appropriate technologies and application characteristics of energy-saving renovation of public buildings in hot summer and cold winter zones. Wang et al. [4] took a university located in Jinan Shandong province as an example to investigate the performance of the energy-saving transformation system. He et al. [5] analyzed the problems from various aspects in Karamay Experimental High School, such as heat source, primary circuit, secondary circuit, indoor heating system, and building envelope structure and put forward the corresponding solutions. After taking measures, the system reached the heating standard. After investigating the cold and heat source system of a middle school in cold area, Zhi-yong et al. [6] carried out energy-saving transformation of the original cold and heat source system from three aspects of load forecasting, transformation scheme design, and transformation benefit analysis. $\mathrm{Li}$ [7] used water source heat pump to heat the shaft, which reduced the operating cost by 1.1086 million Chinese Yuan per year.

The application of heat pump in different occasions had also been studied by many scholars. Wu et al. [8] studied the operation characteristics of a closed-loop surface river source heat pump. Li et al. [9] studied the application of seawater-source heat pump in aquaculture. Sun and Li $[10,11]$ used the technology of mine water source heat pump to supply the heating and cooling of industrial area, which had achieved remarkable economic benefits. Liu et al. [12-14] had studied the application of sewage source heat pump in heating. 
In this paper, taking the heating system reconstruction of a waterworks as an example, this paper analyzes the process and thinking of determining the heat source according to the actual situation of the project and comprehensively considers various factors and analyzes the transformation effect.

\section{Project Overview}

A waterworks, located in Linfen City, Shanxi Province, China, was built in the 1980 s with a water supply capacity of $2500 \mathrm{~m}^{3} / \mathrm{h}$. All the water comes from underground. There are 2530 square meters of living buildings such as office building (three floors), 6544 square meters of production buildings such as various water treatment workshops (one floor), 3926 square meters of various water pools, with a total construction area of 13000 square meters, including 9970 square meters of heating construction area. There is no central heating pipe network near the plant area. The heat source was a coal-fired hot water boiler with a rated thermal power of $1400 \mathrm{~kW}$, and the indoor radiator heating system was adopted. When the outdoor temperature was lower than $0^{\circ} \mathrm{C}$, the boiler system started up and run in intermittent heating mode, and the heating lasted for 5 months every year. During the operation, the average indoor temperature was maintained at $16^{\circ} \mathrm{C}$. The average annual consumption of coal was about 700 tons, and the average annual heating cost is 55.1 Chinese Yuan per square meter. The local central heating cost standard is only 23.2 Chinese Yuan per square meter. Thus, the operation cost of the system was very high and the energy waste was serious. At the same time, the local environmental protection policy also began to limit the use of coal-fired boilers, so the energy-saving transformation of heating source was considered.

\section{Determination of Heat Source Type}

The heating load was recalculated according to the enclosure structure, as shown in Table 1 . According to the calculation, the heating load is $648.55 \mathrm{~kW}$, less than half of the original boiler heating power $(1400 \mathrm{~kW})$.

There was no central heating pipe network around the plant area, but there was a natural gas pipeline network. At the same time, the plant was rich in water resources, so gas-fired boilers or water source heat pumps were mainly considered as heat sources. According to the investigation, the local natural gas price was 3.2 Chinese Yuan per cubic meter. Gas cost was calculated as shown in Table 2. The cost of gas is 60.28 Chinese Yuan per square meter, even higher than the original coal cost (55.1 Chinese Yuan per square meter).

The water source of the waterworks is well water with a temperature of $(17 \pm 1)^{\circ} \mathrm{C}$, which is suitable for the operation of water source heat pump units in winter. In addition, the waterworks purifies 60000 cubic meters of water every day and operates 24 hours, which can meet the requirements of water source heat pump units. Based on the above analysis, the feasibility of water source heat pump was mainly considered.

\section{Determination of Water Source Heat Pump Heating Scheme}

4.1. Problems and Analysis of Inconsistency of Supply and Return Water Temperature between Water Source Heat Pump System and Boiler System. According to the actual situation, the water supply temperature of the original boiler system is $80^{\circ} \mathrm{C}$, and the temperature difference between supply and return water was $25^{\circ} \mathrm{C}$. However, for water source heat pump, the highest temperature of heating water is $65^{\circ} \mathrm{C}$, and the temperature difference between supply and return water is generally between $5^{\circ} \mathrm{C}$ and $15^{\circ} \mathrm{C}$ (obtained by investigating the manufacturers of heat pump units). Therefore, if the water source heat pump is used to replace the boiler, the water supply temperature will be reduced, and the water temperature difference between supply and return will be smaller. The decrease of water temperature will lead to the decrease of heat dissipation capacity of the radiator; to keep the heat dissipation constant, it seems necessary to increase the radiator area. At the same time, the smaller temperature difference means more flow.

4.1.1. Determination of Temperature Difference between Supply and Return Water of Heat Pump System. The greater the temperature difference of the heat pump system, the smaller the system resistance loss, the more likely to use the old pipe network. According to the excavation investigation, the main pipe of outdoor heating pipe network in the plant is made of DN 125 welded steel pipe. The specific friction is calculated by taking the temperature difference between supply and return water at $5^{\circ} \mathrm{C}, 7^{\circ} \mathrm{C}$, and $10^{\circ} \mathrm{C}$, and the calculation results are shown in Table 3 . When the temperature difference is $7^{\circ} \mathrm{C}$ and $10^{\circ} \mathrm{C}$, the flow meets the requirements of economic specific friction resistance range (30-100 Pa/m [19]).

4.1.2. The Influence of the Decrease of Water Temperature on the Number of Radiators. Two-pipe heating system was used in most buildings of this project. For the convenience of analysis, the inlet and outlet water temperatures of radiator are equal to the temperature of water supply and return of heat source in the following analysis.

According to formulas (1)-(3) [18], the decrease of Inlet water temperature of radiator will lead to the decrease of heat dissipation of single radiator. In order to keep the indoor heat supply constant, it is necessary to increase the number of radiators. From this point of view, it is necessary to reform the indoor heating system after using heat pump:

$$
\begin{aligned}
t_{p j} & =\frac{t_{s g}+t_{s h}}{2}, \\
q & =0.657\left(t_{p j}-t_{n}\right)^{1.306}, \\
n & =\frac{Q}{q},
\end{aligned}
$$


TABLe 1: Head load of buildings.

\begin{tabular}{lccc}
\hline Building & Floorage $\left(\mathrm{m}^{2}\right)$ & Heat load $(\mathrm{kW})$ & Heating index $\left(\mathrm{W} / \mathrm{m}^{2}\right)$ \\
\hline Office building & 2700 & 183.6 & 68 \\
Advanced water treatment workshop & 2300 & 138 & 60 \\
Chemical feed room & 1300 & 88.4 & 68 \\
Other workshops & 3670 & 238.55 & 65 \\
Total & 9970 & 648.55 & 65.1 \\
\hline
\end{tabular}

TABLE 2: Calculation of gas cost.

\begin{tabular}{|c|c|c|}
\hline Parameter name & Parameter value & Unit \\
\hline Days of heating period & 150 & $\mathrm{~d}$ \\
\hline Heating load & 648.55 & $\mathrm{~kW}$ \\
\hline Inside air calculating temperature for heating & $18[15]$ & ${ }^{\circ} \mathrm{C}$ \\
\hline Outdoor mean air temperature during heating period & $1.1[15]$ & ${ }^{\circ} \mathrm{C}$ \\
\hline Outdoor air temperature for heating calculating & $-6.6[15]$ & ${ }^{\circ} \mathrm{C}$ \\
\hline Annual consumption of heat & $6525.99[16]$ & GJ \\
\hline Calorific value of natural gas & $38.6[17]$ & $\mathrm{MJ} / \mathrm{m}^{3}$ \\
\hline Thermal efficiency of boiler & 0.9 & \\
\hline Natural gas consumption & 187790.09 & $\mathrm{~m}^{3}$ \\
\hline Overall floorage & 9970 & $\mathrm{~m}^{2}$ \\
\hline Gas fee & 60.28 & Chinese Yuan $/ \mathrm{m}^{2}$ \\
\hline
\end{tabular}

Table 3: Calculation of specific friction under different temperature difference.

\begin{tabular}{ccccccc}
\hline Heat load $(\mathrm{kW})$ & $\begin{array}{c}\text { Supply water } \\
\text { temperature }\left({ }^{\circ} \mathrm{C}\right)\end{array}$ & $\begin{array}{c}\text { Return water } \\
\text { temperature }\left({ }^{\circ} \mathrm{C}\right)\end{array}$ & $\begin{array}{c}\text { Temperature difference between } \\
\text { supply and return water }\left({ }^{\circ} \mathrm{C}\right)\end{array}$ & Flow $\left(\mathrm{m}^{3} / \mathrm{h}\right)$ & $\begin{array}{c}\text { Pipe diameter } \\
(\mathrm{mm})\end{array}$ & $\begin{array}{c}\text { Specific frictional } \\
\text { resistance }(\mathrm{Pa} / \mathrm{m})\end{array}$ \\
\hline \multirow{6}{*}{648.55} & 60 & 58 & 7 & 111.5 & 79.5 & 150 \\
& 65 & 55 & 10 & 55.7 & $110.3[18]$ \\
\hline
\end{tabular}

where $n$ is the number of radiators per group, slice/group; $Q$ is the heat release of radiator, $\mathrm{W} /$ group; $q$ is the heat release of each radiator, $\mathrm{W} /$ piece; $t_{p j}$ is the average water temperature in radiator, ${ }^{\circ} \mathrm{C} ; t_{n}$ is the indoor design temperature for heating, ${ }^{\circ} \mathrm{C}$; $t_{s g}$ is the inlet water temperature of radiator, ${ }^{\circ} \mathrm{C}$; and $t_{s h}$ is the outlet water temperature of radiator, ${ }^{\circ} \mathrm{C}$.

However, by investigating the number of radiators and calculating their heating capacity, as shown in Table 4, it can be found that the number of radiators exceeds the actual demand under the original heating conditions $\left(Q_{S}>D_{H L}\right)$. At the same time, the heating capacity under the condition of heat pump is calculated. As shown in Table 4, when the supply and return water temperature is $65 / 58^{\circ} \mathrm{C}$, the indoor temperature is $16^{\circ} \mathrm{C}$, which can meet the standard of the original system.

For the heat pump system, on the one hand, in order to use the original radiator, the temperature of supply and return water should be increased; on the other hand, in order to use the original pipe network, the temperature difference of supply and return water should be increased. If the water supply temperature of the heat pump unit is higher than $65^{\circ} \mathrm{C}$, its working efficiency will decrease significantly. When the water supply temperature is constant and the water temperature difference between supply and return is enlarged, the flow resistance loss of the pipe network will be reduced, but the heat dissipation capacity of the original radiator will also be reduced. When the supply and return water temperature is $65 / 58^{\circ} \mathrm{C}$, the original pipe network and radiator can be used to meet the requirements, and the operation energy consumption can be reduced to the greatest extent.

4.2. Measures to Prevent Heat Pump System from Polluting Water. Using water source heat pump unit, the well water should be directly connected to the evaporator in the unit. In the evaporator, the refrigerant and water exchange heat through the copper tube, which will not pollute the water under normal conditions. However, if there is a rupture of the copper tube, resulting in the leakage of refrigerant, it will cause pollution. In order to prevent this situation, waterwater heat exchanger can be added to completely isolate water source system and refrigerant system. In order to prevent the pollution caused by the pipeline system, highdensity polyethylene is selected as the pipe material, and copper or stainless steel material is selected for the valve.

4.3. Heat Source Reconstruction Scheme of the Waterworks. There are not only static water sources such as pools but also flowing water sources such as various pipelines. The initial investment and operation cost of intake pump can be saved by using the water in the pipeline. The use of the flowing water source can save the cost by not using intake pump. Through field investigation and analysis, it is determined 
TABLE 4: The number of radiators in each building and its heating capacity.

\begin{tabular}{lccc}
\hline Building & $\begin{array}{c}\text { Number of radiators } \\
\text { per square meter, } n \\
\left(\text { slice } / \mathrm{m}^{2}\right)\end{array}$ & $\begin{array}{l}\text { Heat release of each radiator when the supply } \\
\text { and return water temperatures are } 65 / 58^{\circ} \mathrm{C} \text { and } \\
\text { the indoor temperature is } 16^{\circ} \mathrm{C}, q_{2}(\mathrm{~W} / \mathrm{piece})\end{array}$ & $\begin{array}{c}\text { The heat supply per square meter when the } \\
\text { supply return water temperatures are } 65 / \\
58^{\circ} \mathrm{C} \text { and the indoor temperature is } 16^{\circ} \mathrm{C} \\
\left(Q_{\mathrm{s} 2}=q_{2}\right)^{*} n,\left(\mathrm{~W} / \mathrm{m}^{2}\right)\end{array}$ \\
\hline $\begin{array}{l}\text { Office building } \\
\text { Advanced water } \\
\text { treatment }\end{array}$ & 0.69 & 63.48 & 66.7 \\
$\begin{array}{l}\text { workshop } \\
\text { Chemical feed }\end{array}$ & 0.63 & 57.96 & 60.9 \\
room & 0.71 & 65.32 & 68.6 \\
Other workshops & 0.63 & 57.96 & 60.9 \\
\hline
\end{tabular}

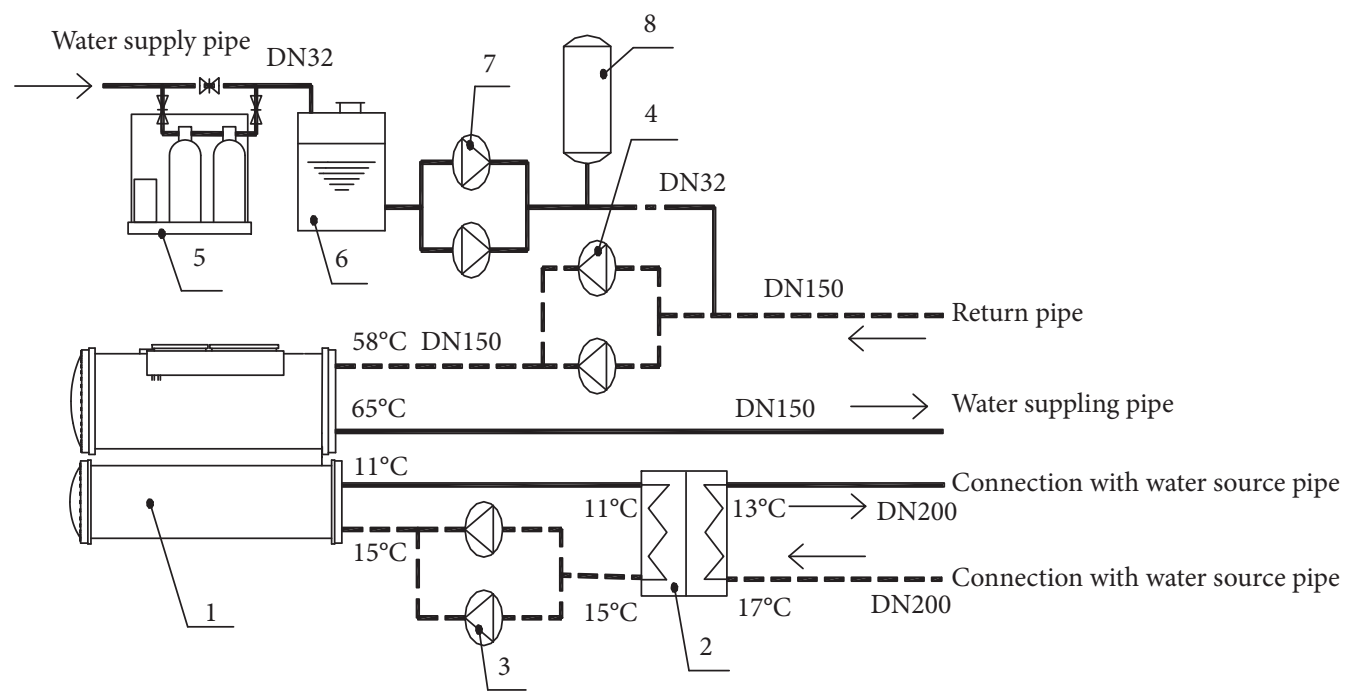

Figure 1: Flow chart of water source heat pump system.

that part of the water from the underground pump house to the advanced water treatment workshop is led out from the water supply pipeline as the water source of the heat pump unit. Based on the above analysis, the process flow of the water source heat pump system was determined, as shown in Figure 1, and the main equipment parameters are shown in Table 5. The system can automatically adjust the water supply temperature according to the outdoor air temperature, which can not only save energy but also save labor management costs.

\section{Economic Analysis of Water Source Heat Pump System}

5.1. Initial Investment and Operation Cost of Water Source Heat Pump System. The reconstruction cost of the system included the equipment, pipeline, and electrical system of the heat pump room, as well as the water intake pipeline, with a total cost of 1.15 million Chinese Yuan.

The water source heat pump system was completed in October 2014 and put into use in November of the same year. It runs 24 hours and lasts for 5 months in each heating season (the central heating time is 4 months). So far, the water source heat pump system has been operating well. The indoor temperature has been kept in the range of $16-18^{\circ} \mathrm{C}$.
After the transformation, the power consumption of the system is shown in Table 6.

5.2. Energy-Saving Analysis Compared with the Original System. Before reconstruction, the annual energy consumption of heating system is $2154000 \mathrm{~kW} \mathrm{~h}$ (as shown in Table 7), at present, the annual power consumption of heat pump heating system is $374126.7 \mathrm{~kW} \mathrm{~h}$ (as shown in Table 6). The energy consumption of the heat pump system is only $17.4 \%$ of that of the original boiler system, and the energy-saving rate reaches $82.6 \%$.

5.3. Economic Analysis Compared with Central Heating. The heat pump system runs five months a year, but the local central heating system runs four months a year. In order to compare the operation costs of the two heating modes, half of the energy in the first month and the last month of the heat pump system operation period is converted, as shown in Table 8. Obviously, the converted system operation cost is only 16.35 Chinese Yuan $/\left(\mathrm{m}^{2} \bullet\right.$ year $)$, but the cost of central heating in this city is 23.2 Chinese Yuan $/\left(\mathrm{m}^{2} \bullet\right.$ year $)$, and the operation cost of the heat pump system is only $70.4 \%$ of the central heating cost. All in all, the heat source transformation is very successful, saving energy and money. 
TABle 5: Parameters of main equipment.

\begin{tabular}{|c|c|c|}
\hline Equipment number & Equipment name & Equipment parameters \\
\hline 1 & Water-source heat pumps & The heating capacity under design condition is $702 \mathrm{~kW}$ \\
\hline 2 & Plate heat exchanger & The heat transfer capacity under design condition is $550 \mathrm{~kW}$ \\
\hline 3 & Circulating water pump & The flow rate is $120 \mathrm{~m}^{3} / \mathrm{h}$, the lift is $8 \mathrm{~m} \mathrm{H}_{2} \mathrm{O}$ \\
\hline 4 & Circulating water pump & The flow rate is $73 \mathrm{~m}^{3} / \mathrm{h}$, the lift is $32 \mathrm{~m} \mathrm{H}_{2} \mathrm{O}$ \\
\hline 5 & Water softener & The water treatment capacity is $1.0 \mathrm{~m}^{3} / \mathrm{h}$ \\
\hline 6 & Soft water tank & The volume is $1.0 \mathrm{~m}^{3}$ \\
\hline 7 & Make-up water pump & The flow rate is $1.0 \mathrm{~m}^{3} / \mathrm{h}$, the lift is $22 \mathrm{~m} \mathrm{H}_{2} \mathrm{O}$ \\
\hline 8 & Pressure tank & The regulating volume is $0.2 \mathrm{~m}^{3}$ \\
\hline
\end{tabular}

TABle 6: Power consumption statistics of the system after transformation.

\begin{tabular}{lccccc}
\hline \multirow{2}{*}{ Month } & & \multicolumn{3}{c}{ Power consumption $(\mathrm{kW} \cdot \mathrm{h})$} \\
& The first year & The second year & The third year & Subtotal & Average value \\
\hline November & 54560 & 39980 & 56340 & 150880 & 50293.33 \\
December & 93860 & 83520 & 89540 & 266920 & 88973.33 \\
January & 93480 & 107160 & 133100 & 333740 & 111246.67 \\
February & 66460 & 86800 & 80200 & 233460 & 77820.00 \\
March & 34700 & 56480 & 46200 & 137380 & 45793.33 \\
Total & 343060 & 373940 & 405380 & 1122380 & 374126.67 \\
\hline
\end{tabular}

TABLE 7: Energy consumption of original system.

\begin{tabular}{lccc}
\hline Name & Number/power & $\begin{array}{c}\text { Coal consumption rate of power supply/operation } \\
\text { time of circulating pump }\end{array}$ & $\begin{array}{c}\text { Equivalent electric } \\
\text { energy consumption }\end{array}$ \\
\hline Coal & $700 \mathrm{t}$ & $333 \mathrm{~g} / \mathrm{kW} \bullet \mathrm{h}[20]$ & $2100000 \mathrm{~kW} \bullet \mathrm{h}$ \\
Circulating pump & $20 \mathrm{~kW}$ & 2700 hours & $54000 \mathrm{~kW} \bullet \mathrm{h}$ \\
& Equivalent power consumption of original system & $2154000 \mathrm{~kW} \bullet \mathrm{h}$ \\
\hline
\end{tabular}

TABLE 8: Converted operating cost of heat pump system.

\begin{tabular}{|c|c|c|c|c|c|c|}
\hline Month & $\begin{array}{c}\text { Actual power } \\
\text { consumption in } \\
\text { three years }(\mathrm{kW} \cdot \mathrm{h})\end{array}$ & $\begin{array}{l}\text { Converted power } \\
\text { consumption in } \\
\text { three years }(\mathrm{kW} \cdot \mathrm{h})\end{array}$ & $\begin{array}{l}\text { Unit price of } \\
\text { electricity } \\
\text { (Chinese } \\
\text { Yuan } / \mathrm{kW} \cdot \mathrm{h} \text { ) }\end{array}$ & $\begin{array}{c}\text { Average annual } \\
\text { converted electric } \\
\text { charge (Chinese } \\
\text { Yuan) }\end{array}$ & Floorage $\left(\mathrm{m}^{2}\right)$ & $\begin{array}{l}\text { Average annual } \\
\text { electricity charge per } \\
\text { unit area (Chinese } \\
\left.\text { Yuan } /\left(\mathrm{m}^{2} \bullet \text { year }\right)\right)\end{array}$ \\
\hline November & 150880 & 75440 & \multirow{6}{*}{0.5} & 37720 & \multirow{6}{*}{9970} & 1.26 \\
\hline December & 266920 & 266920 & & 133460 & & 4.46 \\
\hline January & 333740 & 333740 & & 166870 & & 5.58 \\
\hline February & 233460 & 233460 & & 116730 & & 3.90 \\
\hline March & 137380 & 68690 & & 34345 & & 1.15 \\
\hline Total & 1122380 & 978250 & & 489125 & & 16.35 \\
\hline
\end{tabular}

\section{Conclusion}

(1) For projects with abundant water resources, such as waterworks, it is a relatively economic scheme to use water source heat pump in winter. The operation cost of water source heat pump system is only $70.4 \%$ of the cost of central heating in local cities.

(2) In some heating transformation projects of heat pump replacing boiler, although the temperature of supply and return water decreases, it is not necessary to increase the number of radiators, which needs to be calculated and verified according to the actual situation. This is caused by the excessive number of radiators in the original system.
(3) For waterworks, when water source heat pump unit is used as heating source, it is necessary to take measures to prevent water pollution, such as setting heat exchanger.

\section{Data Availability}

The data used to support the findings of this study are included within the article.

\section{Conflicts of Interest}

The authors declare that there are no conflicts of interest regarding the publication of this article. 


\section{References}

[1] H. Chunxu, A. Qu, Z. Dong, J. Qin, Z. Go, and R. Hu, "Study on subsidy policy of clean heating environment in North China," Ecological Economy, vol. 36, no. 4, pp. 151-155, 2020, (in Chinese).

[2] W. Yu, R. Jia, X. Xia, H. Zheng, and B. Hu, "Analysis of the current situation and marketing for "Coal to electricity" in Shanxi province," Shandong Electric Porer, vol. 47, no. 270, pp. 61-64, 2020, (in Chinese).

[3] W. Zhang, "Technical analysis and energy efficiency evaluation of energy saving renovation of public buildings in hot summer and cold winter zone," $H V \mho A C$, vol. 50, no. 5, pp. 67-70, 2020, (in Chinese).

[4] X. Wang, X. Zhou, and P. Cui, "A case study for the energysaving transformation of an existing heating system in an university," District Heating, vol. 2, pp. 33-42, 2019, (in Chinese).

[5] J. He and X. Guo, "Analysis and solutions of heating system problems in Karamay experimental high school," Energy and Energy Conservation, vol. 171, no. 12, pp. 88-90, 2019, (in Chinese).

[6] L. Zhi-yong, D. Nai-ren, and F. Liu, "Feasibility analysis of a high school in cold regions design project for energy retrofit," Energy Conserbation, vol. 379, no. 4, pp. 29-32, 2014, (in Chinese).

[7] X. Li, "Analysis of heat source reforming scheme of antifreezing heating in zhaogu No. 2 Mine," Coal and Chemical Industry, vol. 43, no. 8, pp. 95-97, 2020, (in Chinese).

[8] S. Wu, F. Yun-zhun, and C. Li-jie, "Experimental study on refrigeration operation characteristics of a close-loop surface river source heat pump system," Fluid Machinery, vol. 46, no. 10, (in Chinese), 2018.

[9] X. Li, W. Deng, D. Zhang, Z. G. MuGan, S. Chen, and Q. Che, "Engineering application of seawater-source heat pump for waste heat recovery in sea cucumber breeding system," Transactions of the Chinese Society of Agricultural Engineering, vol. 33, no. 9, pp. 218-223, 2017, (in Chinese).

[10] X. Sun and S. Zhu, "Analysis of winter operating performance and economy of a mine water source heat pump system," Building Science, vol. 34, no. 2, pp. 49-54, 2018, (in Chinese).

[11] K.-r. Li, "Mine water waste heat utilization in Tangjiahui Coal Mine," Coal Engineering, vol. 52, no. 7, pp. 24-26, 2020, (in Chinese).

[12] X. Liu, Z. Yin, C. Liang, Z. Li, and C. Wang, "Study on the actual application effect of sewage source heat pump in a green building in a cold region during the heating season," Building Science, vol. 34, no. 8, pp. 10-17, 2018, (in Chinese).

[13] X. Jia, M. Duan, and H. Shu, "Field measurement and energysaving potential analysis on the performance of a sewagewater heat pump system," Journal of Refrigeration, vol. 38, no. 6, pp. 66-72, 2017, (in Chinese).

[14] P. Chun-ying, K. Liu, J. Zheng, H. Deng-yue, G. Wen-bao, and L. Yu-hong, "Application research of sewage source heat pump for heating of WWTP," China Water\&Wastewater, vol. 27, no. 17, pp. 91-95, 2011, (in Chinese).

[15] Ministry of Housing and Urban-Rural Development of the People's Republic of China, Design Code for Heating Ventilation and Air Conditioning of Civil Buildings(GB 507362012), China Architecture \& Building Press, Beijing, China, 2012pp. 6-107, (in Chinese).

[16] Ministry of Housing and Urban-Rural Development of the People's Republic of China, Design Code for City Heating
network(CJJ34-2010), China Architecture \& Building Press, Beijing, China, 2011pp. 9-11, (in Chinese).

[17] X. Liu and J. Zhu, "Water-loop heat pump was applied in space heating in winter," Acta Energiae Solaris Sinica, vol. 26, no. 2, pp. 262-265, 2005, (in Chinese).

[18] Y. Lu, Practical Heating and Air Conditioning Design ManualChina Architecture Publishing Press, Beijing, China, Second edition, pp. 53-401, Beijing, China, 2008, (in Chinese).

[19] Department of Construction Engineering Quality \& Safety Supervision Ministry of Housing and Urban-Rural Development of the P. R. China, "China Institute of Building Standard Design \& Research," in National Technical Measures for Design of Civil Construction(2009)-Heating, Ventilation and Air Conditioning, pp. 50-51, China Planning Press, Beijing, China, 2009, (in Chinese).

[20] Y. Yang, Z. Yang, G. Xu, and N. Wang, "Situation and prospect of energy consumption for China's thermal power generation," in Proceedings of the CSEE, vol. 33, no. 23, pp. 1-12, 2013, (in Chinese). 